\title{
EMOTIONAL INTELLIGENCE, SELF-ESTEEM \\ AND ACADEMIC ACHIEVEMENT: \\ A CASE STUDY, ENGLISH DEPARTMENT STUDENTS
}

\author{
Wiwik Andreani \\ English Department, Faculty of Humanities, BINUS University \\ Jln. Kemanggisan Ilir III No. 45, Kemanggisan - Palmerah, Jakarta Barat 11480 \\ wiwik@binus.edu
}

\begin{abstract}
This study examines the comparison between English Department students' emotional intelligence (EQ), their self-esteem and their academic achievement. Twenty-two students participated in the research by answering EQ test and two Self-Esteem questionnaires. The result shows that there is no relation between students' GPA and their self-esteem and EQ. This means that academic ability does not correspond to social skills. Though most students have average EQ and self-esteem, one student has High EQ, High Self-esteem and a 2.95 GPA (out of 4).
\end{abstract}

Keywords: emotional intelligence, students' self-esteem, academic achievement

\begin{abstract}
ABSTRAK
Penelitian ini membahas tentang perbandingan antara kecerdasan emosi mahasiswa jurusan Sastra Inggris dengan kepercayaan diri dan prestasi akademik mereka. Dua puluh dua siswa berpartisipasi dalam menjawab tes EQ dan dua kuesioner kepercayaan diri. Hasil menunjukkan bahwa tidak ada hubungan antara IPK mahasiswa dengan kepercayaan diri dan EQ mereka. Ini berarti bahwa kemampuan akademik tidak berhubungan dengan keterampilan sosial. Meskipun kebanyakan siswa memiliki EQ dan kepercayaan diri ratarata, satu siswa memiliki tingkat EQ tinggi, kepercayaan diri yang tinggi, dan IPK 2.95 (dari 4).
\end{abstract}

Kata kunci: kecerdasan emosi, kepercayaan diri siswa, prestasi akademik 


\section{INTRODUCTION}

In his research, Martin Yate (1977, in Singh, 2006) found out that emotional intelligence has an important role in determining someone's success in his work. He also stated that different kinds of jobs need different levels of emotional intelligence. The levels of emotional intelligence someone needs depend on the frequency he has to interact with other people, work in a team, empathize and understand other people. Nowadays, it is believed that besides academic intelligence, emotional intelligence is badly needed by every student in his study. At least, we, as teachers, want our students to have both academic ability and social skills. However, in reality, not all students have both of them. Therefore the study is meant to find out the relationship between those two: academic ability and social skills. The academic ability is represented by the students' GPA, while the social skills are measured by EQ test and Self-Esteem Questionnaire. Furthermore the research was done in two Grammar classes the researcher taught. The two classes were totally different. The students in class A were smart, serious and quiet. On the other hand, the students in class B were 'weak' but they seemed not to be bothered with their academic achievement. They seemed to enjoy their friends' company and they did not pay much attention to the lesson explained in the classroom. A question is raised, then: When a student does not get good scores, does he still feel good about himself? Does he have positive view of himself? How about his emotional intelligence?

Based on the condition, there is one problem to be solved in the study: What is the comparison of the students' academic achievement (GPA) with their emotional intelligence and their self-esteem?

\section{Emotional Intelligence}

The theory of Emotional Intelligence was popularized by Daniel Goleman in the mid-90s. Goleman (1998) defines EQ as "the capacity for recognizing our own feelings and those of others, for motivating ourselves, and for managing emotions well in ourselves and in our relationships. Emotional intelligence describes abilities distinct from, but complementary to, academic intelligence or the purely cognitive capacities measured by IQ.” Besides Goleman, Bar-On (1997) states that "emotional intelligence reflects one's ability to deal with daily environment challenges and helps predict one's success in life, including professional and personal pursuits." From those definitions, it can be concluded that emotional intelligence is a must-have ability owned by everybody, including university students and it can be practiced and improved while they are studying.

Robert H. Vela, Jr. (2003) wrote his dissertation on the role of emotional intelligence in the academic achievement of first year college students. The subjects of the study included 760 first year college students from a selected university in South Texas. The results of the study show that there is a significant correlation between emotional intelligence skills and the academic achievement according to gender and ethnicity. This study is different from Robert's research since it covers not only emotional intelligence, but also self-esteem. It wants to discover whether having good academic achievement always results in having high self-esteem as well.

\section{Self-Esteem}

There are a lot of definitions of self-esteem. Baumeister, 1998 in Lopez and Snyder (2009) defines it as "self-esteem is the evaluative aspect of the self-concept that corresponds to an overall view of the self as worthy or unworthy". This is in line with Coopersmith's (1967) definition in Lopez and Snyder (2009):

"Self-esteem is the evaluation which the individual makes and customarily maintains with regard to himself: it expresses an attitude of approval and indicates the extent to which an individual believes himself to be capable, significant, successful and worthy. In short, self-esteem is a personal judgment of the worthiness that is expressed in the attitudes the individual holds towards himself." 
Another definition of self-esteem comes from the sociometer theory which says that "selfesteem functions as a monitor of the likelihood of social exclusion. When people behave in ways that increase the likelihood they will be rejected, they experience a reduction in state self-esteem. Thus, self-esteem serves as a monitor, or sociometer, of social acceptance - rejection” (Lopez and Snyder, 2009). Therefore usually people who have high self-esteem are not worried about how they are being perceived by others since they have sociometers or monitors that show rejection is something very unlikely they experience. On the other hand, those having low self-esteem think that public impressions are crucial for them because they need to be socially accepted.

Self-esteem have three major components: performance self-esteem, social self-esteem, and physical self-esteem (Heatherton \& Polivy, 1991 in Lopez and Snyder, 2009). Academic achievement is included in performance self-esteem, while other people's perception belongs to social self-esteem. Lastly, physical bodies and attractions are examples of physical self-esteem.

\section{Participants}

The participants of the study were two Grammar classes of the second semester students of the English Department, Bina Nusantara University, Jakarta: class A and class B, eleven students from each class, so the total is twenty-two students. Class A was a regular class, held during even semester, 2010/2011 academic year, while class B was held during short semester. All students taking short semester were repeaters from the previous semester (even semester). They were 'weak' students and they were not enthusiastic since the course held them from going for a long holiday because the short semester was held during the long holiday between even semester 2010/2011 and odd semester 2011/2012 (July-August, 2011). In my observation, the students in these two classes were totally different. Class A included students who regarded academic achievement as something very important and it was worth fighting for. However, class B students were contrary to class A students. In spite of the fact that they repeated the Grammar course, they were all happy students. They were not bothered by the bad scores they got in the Grammar quizzes; they were not serious in the classroom.

\section{RESEARCH METHODS}

In this study, the data were collected according to the following methods:

Table1 Schedule of EQ and Self-Esteem questionnaire distribution

\begin{tabular}{|c|c|c|c|}
\hline No & Activities & Place - Time & Description \\
\hline 1 & $\begin{array}{l}\text { Students of Class B were given } \\
\text { Self-esteem questionnaire }\end{array}$ & $\begin{array}{l}\text { In the classroom, during short } \\
\text { semester }\end{array}$ & $\begin{array}{l}\text { Rosenberg - Scale } \\
\text { questionnaire }\end{array}$ \\
\hline 2 & $\begin{array}{l}\text { Students of Class B were given } \\
\text { another self-esteem questionnaire }\end{array}$ & $\begin{array}{l}\text { In the classroom, during short } \\
\text { semester, one week after } \\
\text { Rosenberg-Scale questionnaire }\end{array}$ & $\begin{array}{l}\text { Current condition self-esteem } \\
\text { questionnaire }\end{array}$ \\
\hline 3 & $\begin{array}{l}\text { Students of Class B were given } \\
\text { EQ test }\end{array}$ & $\begin{array}{l}\text { In the classroom, during short } \\
\text { semester, one week after Current } \\
\text { condition self-esteem questionnaire }\end{array}$ & $\begin{array}{l}\text { EQ test (constructed from } \\
\text { Goleman) }\end{array}$ \\
\hline 4 & $\begin{array}{l}\text { Students of Class A were given } \\
\text { self-esteem questionnaire }\end{array}$ & $\begin{array}{l}\text { Through email, outside the } \\
\text { classroom }\end{array}$ & $\begin{array}{l}\text { Rosenberg - Scale } \\
\text { questionnaire }\end{array}$ \\
\hline 5 & $\begin{array}{l}\text { Students of Class A were given } \\
\text { another self-esteem questionnaire }\end{array}$ & $\begin{array}{l}\text { In the classroom, during regular } \\
\text { semester, after Rosenberg-scale } \\
\text { questionnaire }\end{array}$ & $\begin{array}{l}\text { Current condition self-esteem } \\
\text { questionnaire }\end{array}$ \\
\hline 6 & $\begin{array}{l}\text { Students of Class B were given } \\
\text { EQ test }\end{array}$ & $\begin{array}{l}\text { Through email, outside the } \\
\text { classroom }\end{array}$ & $\begin{array}{l}\text { EQ test (constructed from } \\
\text { Goleman) }\end{array}$ \\
\hline
\end{tabular}


From table 1, it can be seen that every student had to answer two types of self-esteem questions and one type of EQ test. The Rosenberg Self-Esteem questionnaire measures the students' self-esteem in general, while the Current Condition Self-esteem questionnaire measures their selfesteem at that moment, the moment when they answered the questionnaire. By comparing the two self-esteem questionnaires, it is hoped that we can draw a more accurate description of the students' self-esteem. The Rosenberg Self-Esteem scale (1965) is used because it is a measure of global selfesteem that is most widely used (Demo, 1985 in Lopez and Snyder, 2009). The EQ test is constructed from Goleman's theory (1995), which consists of 183 questions covering self-awareness, selfmanagement, motivation, empathy and social skills.

The completed measure of self-esteem and EQ test were checked and the answers were classified into Low, High and Average Level, according to Mean and Standard deviation.

\section{RESULTS AND DISCUSSION}

Table 2 Result of EQ test (Class B, short semester / SM)

\begin{tabular}{ccccc}
\hline No & Name & EQ & Description & GPA \\
\hline 1. & Student 1-SM & 642 & Average & 1.79 \\
2. & Student 2-SM & 618 & Average & 2.94 \\
3. & Student 3-SM & 557 & Low & 2.75 \\
4. & Student 4-SM & 659 & Average & 2.39 \\
5. & Student 5-SM & 629 & Average & 2.42 \\
6. & Student 6-SM & 682 & High & 2.95 \\
7. & Student 7-SM & 626 & Average & 1.76 \\
8. & Student 8-SM & 620 & Average & 1.76 \\
9. & Student 9-SM & 612 & Average & 2.1 \\
10. & Student 10-SM & 730 & High & 1.5 \\
11. & Student 11-SM & 575 & Low & 1.71 \\
\hline
\end{tabular}

From Table 2, it can be seen that from the short semester class, two students have Low EQ, two students have High EQ and the rest (seven students) have Average EQ.

Table 3 Result of EQ test (Class A, regular semester / Reg)

\begin{tabular}{ccccc}
\hline No & Name & EQ & Description & GPA \\
\hline 12 & Student 12 - Reg & 590 & Average & 3.6 \\
13 & Student 13 - Reg & 630 & Average & 3.45 \\
14 & Student 14 - Reg & 621 & Average & 3.8 \\
15 & Student 15 - Reg & 634 & Average & 3.6 \\
16 & Student 16 - Reg & 568 & Low & 3.55 \\
17 & Student 17 - Reg & 638 & Average & 3.3 \\
18 & Student 18 - Reg & 572 & Low & 3.3 \\
19 & Student 19 - Reg & 681 & High & 3.2 \\
20 & Student 20 - Reg & 556 & Low & 3.05 \\
21 & Student 21 - Reg & 614 & Average & 3.25 \\
22 & Student 22 - Reg & 594 & Average & 3.65 \\
\hline
\end{tabular}


Tables 2 and 3 indicate that class B (short semester class) is better than class A (regular class) in terms of the number of High EQ and Low EQ students. Surprisingly, Class B has two students with High EQ and two Low EQ students, while class A only has one student with High EQ and three students with Low EQ. Thus, in this case having good GPA seemingly does not guarantee High EQ, while having low GPA does not always mean Low EQ.

Table 4 Comparison of Rosenberg Scale Self-Esteem and Current Self-Esteem

\begin{tabular}{|c|c|c|c|c|c|c|}
\hline No & Nama & Rosenberg & Description & Current & Description & GPA \\
\hline 1 & Student 1 - SM & 20 & Average & 75 & Average & 1.79 \\
\hline 2 & Student 2 - SM & 18 & Average & 63 & Average & 2.94 \\
\hline 3 & Student 3 - SM & 10 & Low & 47 & Low & 2.75 \\
\hline 4 & Student 4 - SM & 21 & Average & 71 & Average & 2.39 \\
\hline 5 & Student 5 - SM & 16 & Average & 54 & Low & 2.42 \\
\hline 6 & Student 6 - SM & 28 & High & 84 & High & 2.95 \\
\hline 7 & Student 7 - SM & 16 & Average & 59 & Average & 1.76 \\
\hline 8 & Student 8 - SM & 25 & Average & 82 & High & 1.76 \\
\hline 9 & Student 9 - SM & 20 & Average & 66 & Average & 2.1 \\
\hline 10 & Student 10 - SM & 15 & Average & 60 & Average & 1.5 \\
\hline 11 & Student 11 - SM & 24 & Average & 68 & Average & 1.71 \\
\hline 12 & Student 12 - Reg & 25 & Average & 75 & Average & 3.6 \\
\hline 13 & Student 13 - Reg & 25 & Average & 77 & Average & 3.45 \\
\hline 14 & Student 14 - Reg & 23 & Average & 77 & Average & 3.8 \\
\hline 15 & Student 15 - Reg & 15 & Average & 74 & Average & 3.6 \\
\hline 16 & Student 16 - Reg & 14 & Low & 53 & Low & 3.55 \\
\hline 17 & Student 17 - Reg & 17 & Average & 67 & Average & 3.3 \\
\hline 18 & Student 18 - Reg & 19 & Average & 57 & Low & 3.3 \\
\hline 19 & Student 19 - Reg & 25 & Average & 80 & High & 3.2 \\
\hline 20 & Student 20 - Reg & 18 & Average & 71 & Average & 3.05 \\
\hline 21 & Student 21 - Reg & 22 & Average & 68 & Average & 3.25 \\
\hline 22 & Student 22 - Reg & 17 & Average & 69 & Average & 3.65 \\
\hline
\end{tabular}

The previous table (Table 4) shows that there are two students who have differences in the evaluation of self-esteem: student 5 and 18 (Average - Low). In general it can be said that the two students have average self-esteem while at the time of completing the test, they might have some problems so that the results are low self-esteem. In contrast, there are two other students (student 8 and 19) whose answers indicate two kinds of self-esteem (Average - High). It might happen because at the time of doing the self-esteem scale, they were happy with themselves. The rest of them have the same result for the two tests and only one student has high self-esteem for both questionnaires (student 6). When we look at the student's GPA, he / she does not have a very high GPA (2.95). Students 3 and 16 have low self-esteem in spite of their good / high GPA (2.75 and 3.55). This probably happens because they are concerned too much about how other people perceive them (sociometer theory) and they have worked very hard to get good scores. Most of the students have average self-esteem, meaning that they still have to undergo a long process to improve their self-esteem and they are probably not experienced yet since they are still in their second semester. 
Table 5 Result of two Self-Esteem Scales, EQ and GPA

\begin{tabular}{cccccc}
\hline No & Nama & Rosenberg Scale & Current Scale & GPA & EQ \\
\hline 1 & Student 1 - SM & Average & Average & 1.79 & Average \\
2 & Student 2 - SM & Average & Average & 2.94 & Average \\
3 & Student 3 - SM & Low & Low & 2.75 & Low \\
4 & Student 4 - SM & Average & Average & 2.39 & Average \\
5 & Student 5 - SM & Average & Low & 2.42 & Average \\
6 & Student 6 - SM & High & High & 2.95 & High \\
7 & Student 7 - SM & Average & Average & 1.76 & Average \\
8 & Student 8 - SM & Average & High & 1.76 & Average \\
9 & Student 9 - SM & Average & Average & 2.1 & Average \\
10 & Student 10 - SM & Average & Average & 1.5 & High \\
11 & Student 11 - SM & Average & Average & 1.71 & Low \\
12 & Student 12 - Reg & Average & Average & 3.6 & Average \\
13 & Student 13 - Reg & Average & Average & 3.45 & Average \\
14 & Student 14 - Reg & Average & Average & 3.8 & Average \\
15 & Student 15 - Reg & Average & Average & 3.6 & Average \\
16 & Student 16 - Reg & Low & Low & 3.55 & Low \\
17 & Student 17 - Reg & Average & Average & 3.3 & Average \\
18 & Student 18 - Reg & Average & Low & 3.3 & Low \\
19 & Student 19 - Reg & Average & High & 3.2 & High \\
20 & Student 20 - Reg & Average & Average & 3.05 & Low \\
21 & Student 21 - Reg & Average & Average & 3.25 & Average \\
22 & Student 22 - Reg & Average & Average & 3.65 & Average \\
\hline
\end{tabular}

From table 5, it can be seen that there are fifteen students (68\%) who show consistency in the two self-esteem scale and EQ score: twelve students (54.5\%) - average, two students (9\%) - low, and only one student (4.5\%) - high. However, when we compare only Rosenberg Self-Esteem Scale and EQ Score, there are seventeen students (64\%) who show consistency: fourteen students (64\%) average, two students (9\%) - low, and one student (4.5\%) - high. The rest of them (five students 23\%) show inconsistency, for example they have average self-esteem but low EQ score, or average self-esteem but high EQ score. Finally, when the students' GPA is examined, it seems that the GPA does not correspond with the result of the self-esteem scale and EQ.

\section{CONCLUSION}

From the analysis, it can be concluded that academic achievement is not everything. When a student does not get high scores, it does not mean that he is not good in any other aspects, since high scores refers to performance self-esteem, and other aspects he has may belong to other dimensions of self-esteem, which are his social self-esteem and physical self-esteem, the two of which are measured by the Rosenberg Self-Esteem scale, Current Self-Esteem scale and EQ test. The study found out that despite the Low GPA the students got, they still have average, even high self-esteem. On the other hand, students having good GPA do not automatically have high EQ and self-esteem. This is surely a challenge for educators to continuously help the students improve both cognitively and emotionally so that they will be successful leaders in the future. 


\section{REFERENCES}

Bar-On, R. (2010). Emotional Intelligence: An Integral Part of Positive Psychology, South African Journal of Psychology, 40(1), 54-62.

Goleman, D. (1995). Emotional Intelligence. New York: Bantam.

(1998). Working with Emotional Intelligence. New York: Bantam.

Lopez, S.J. and C.R. Snyder. (2009). Positive psychological assessment: a handbook of models and measures. Washington, DC: APA

Singh, D. (2006). Emotional Intelligence At Work. A Professional Guide. 3rd edition. New Delhi, India: Response Book.

Vela, R.H. Jr. (2003). The role of emotional intelligence in the academic achievement of first year college students. A dissertation. 